\title{
Keratinized Tissue Assessment for Dental Implant Therapy
}

\author{
Amit S Gharpure, ${ }^{1 *}$ Arti S Gharpure ${ }^{2}$ \\ ${ }^{1}$ Affiliate Instructor, Graduate Periodontics, University of Washington School of Dentistry, USA \\ ${ }^{2}$ DDS Candidate, University of Michigan School of Dentistry, USA
}

\section{Editorial}

Although overall failure rates in implant dentistry are low, ${ }^{1}$ peri-implant diseases have been recognized as a common biologic complication that can reduce the long-term success of dental implants. ${ }^{2}$ A recent systematic review and meta-analysis reported prevalence of peri-implant mucositis and peri-implantitis to be at $65 \%$ and $47 \%$, respectively. ${ }^{3}$ Peri-implant mucositis and peri-implantitis are biofilm-associated, inflammatory conditions of peri-implant tissues. ${ }^{4}$ There has been significant evidence implying the role of bacterial plaque in the initiation of inflammatory responses in the gingiva of natural teeth as well as peri-implant mucosa. ${ }^{5,6}$ Peri-implant disease etiology is multi factorial in nature, ${ }^{7}$ and numerous factors may contribute to plaque accumulation and subsequent inflammation, playing a role as risk indicators for the development of peri-implant disease. , $^{2,8}$,

The anatomy and histology of the mucosal attachment around dental implants is considerably different from that around natural teeth. ${ }^{10,11} \mathrm{~A}$ direct anchorage of the connective tissue to the implant surface is not possible due the absence of periodontal ligament and cementum as seen in natural teeth. Instead, collagen fibers run parallel to the implant surface and the mechanical quality of this attachment is low. ${ }^{10,11}$ On a biologic level, it would be favorable to have a zone of keratinized tissue around dental implants. However, the need for keratinized tissue around implants is highly debated. There have been several studies which have documented positive associations between the presence of adequate keratinized mucosa around implants and improved soft tissue health. ${ }^{12-14}$ Further, the lack of keratinized tissue around implants has been demonstrated to make the peri-implant region more susceptible to plaque-induced tissue destruction. ${ }^{15}$ Painful oral hygiene has been reported due to the absence of the keratinized tissue surrounding implants, and this has been attributed to the mechanical irritation caused by the mobility of the non keratinized tissue under function. ${ }^{14,16}$ Conversely, limited need for keratinized tissues around implants to maintain health and tissue stability has also been shown. ${ }^{17}$ However, it must be noted that the majority of systematic reviews have indicated a positive relation between presence of keratinized tissue around implants and clinical parameters such inflammation and plaque accumulation. ${ }^{18-21}$ Thus, available literature on the subject indicates that keratinized mucosa around implants may improve the predictability of implant based treatment. However, further evidence is needed to establish the role of keratinized tissue width and gingival phenotype in peri-implant disease. ${ }^{22}$

Although there have been few publications on the importance of keratinized tissue around dental implants, and described techniques to augment this tissue ${ }^{23-25}$ the timing and sequencing of soft-tissue grafts has not been sufficiently addressed. After a thorough clinical assessment, if a major correction of soft tissue is necessary (more than $2 \mathrm{~mm}$ of keratinized mucosa needs to be augmented at the proposed implant site), a soft tissue augmentation procedure needs to be performed first which may be carried out at the time of implant placement. Several systematic reviews have compared available soft tissue augmentation procedures, ${ }^{23-25}$ and all the compared techniques have provided adequate results, with no technique indicating substantial superiority over others. Free gingival grafts as well as connective tissue grafts in combination with an apically positioned flap/vestibuloplasty have established reliable results to increase the width of the keratinized gingiva, ${ }^{26,27}$ and they may be utilized when a soft tissue correction of more than $1 \mathrm{~mm}$ is required. For minor soft tissue corrections (in which a total of less than $1 \mathrm{~mm}$ of the soft tissue needs to be augmented), a sec-

\begin{tabular}{|l|l|}
\hline Quick Response Code: & *Corresponding author: Amit S Gharpure, Periodontics, University of Washington School of \\
Dentistry, 1959 NE Pacific St, HSC, D-570, Box 357444, Seattle, WA 98195-744, USA \\
Received: 20 March, 2021 \\
Citation: Amit SG, Arti SG. Keratinized Tissue Assessment for Dental Implant Therapy. SOJ Den \\
Oral Disor. 2021;1(2):1-2. DOI: 10.53902/SOJDOD.2021.01.000509
\end{tabular}


ond stage approach may be utilized at the time of implant uncovery. Techniques such as roll envelope flap can also be successfully used at second stage implant surgery for minor corrections. ${ }^{26}$ Thus, at the time of clinical examination for implant placement, it is critical to identify whether adequate keratinized tissue is available at the implant site and treatment plan the necessary soft tissue augmentation procedure if it is insufficient.

\section{Acknowledgments}

None.

\section{Funding}

There was no support in the form of funding for this study.

\section{Conflict of Interest}

The authors declare that there was no conflict of interest.

\section{References}

1. Albrektsson T, Donos N. Implant survival and complications. The Third EAO consensus conference 2012. Clin Oral Implants Res. 2012;23Suppl 6:63-65.

2. Daubert DM, Weinstein BF, Bordin S, et al. Prevalence and predictive factors for peri-implant disease and implant failure: a cross-sectional analysis. J Periodontol. 2015;86(3):337-347.

3. Derks J, Tomasi C. Peri-implant health and disease. A systematic review of current epidemiology. J Clin Periodontol. 2015;42 Suppl 16:S158-171.

4. Caton JG, Armitage G, Berglundh T, et al. A new classification scheme for periodontal and peri-implant diseases and conditions- Introduction and key changes from the 1999 classification. J Periodontol. 2018;89 Suppl 1:S1-S8.

5. Zitzmann NU, Berglundh T, Marinello CP, et al. Experimental peri-implant mucositis in man. J Clin Periodontol. 2001;28(6):517-523.

6. Heitz-Mayfield LJA, Salvi GE. Peri-implant mucositis. J Periodontol. 2018;89Suppl 1:S257-S266.

7. Sarmiento HL, Norton MR, Fiorellini JP. A Classification System for Periimplant Diseases and Conditions. Int J Periodontics Restorative Dent. 2016;36(5):699-705.

8. Katafuchi M, Weinstein BF, Leroux BG, et al. Restoration contour is a risk indicator for peri-implantitis: A cross-sectional radiographic analysis. $J$ Clin Periodontol. 2018;45(2):225-232.

9. Dixon DR, London RM. Restorative design and associated risks for periimplant diseases. Periodontol 2000. 2019;81(1):167-178.

10. Abrahamsson I, Berglundh T, Wennstrom J, et al. The peri-implant hard and soft tissues at different implant systems. A comparative study in the dog. Clin Oral Implants Res. 1996;7(3):212-219.

11. Lindhe J, Berglundh T. The interface between the mucosa and the implant. Periodontol 2000. 1998;17(1):47-54.

12. Bouri AJr,Bissada N, Al-Zahrani MS, et al. Width of keratinized gingiva and the health status of the supporting tissues around dental implants. Int J Oral Maxillofac Implants. 2008;23(2):323-326.
13. Schrott AR, Jimenez M, Hwang JW, et al. Five-year evaluation of the influence of keratinized mucosa on peri-implant soft-tissue health and stability around implants supporting full-arch mandibular fixed prostheses. Clin Oral Implants Res. 2009;20(10):1170-1177.

14. Adibrad M, Shahabuei M, Sahabi M. Significance of the width of keratinized mucosa on the health status of the supporting tissue around implants supporting overdentures. J Oral Implantol. 2009;35(5):232237.

15. Warrer K, Buser D, Lang NP, et al. Plaque-induced peri-implantitis in the presence or absence of keratinized mucosa. An experimental study in monkeys. Clin Oral Implants Res. 1995;6(3):131-138.

16. Kaptein MLA, De Lange GL, Blijdorp PA. Peri-implant tissue health in reconstructed atrophic maxillae-report of 88 patients and 470 implants. J Oral Rehabil. 1999;26(6):464-474.

17. Wennstrom JL, Derks J. Is there a need for keratinized mucosa around implants to maintain health and tissue stability? Clin Oral Implants Res. 2012;23Suppl 6:136-146.

18. Lin GH, Chan HL, Wang HL. The significance of keratinized mucosa on implant health: a systematic review. J Periodontol. 2013;84(12):17551767.

19. Meffert RM, Langer B, Fritz ME. Dental implants: a review. J Periodontol. 1992;63(11):859-870.

20. Gobbato L, Avila-Ortiz G, Sohrabi K, Wang CW, Karimbux N. The effect of keratinized mucosa width on peri-implant health: a systematic review. Int J Oral Maxillofac Implants. 2013;28(6):1536-1545.

21. Brito C, Tenenbaum HC, Wong BK,et al. Is keratinized mucosa indispensable to maintain peri-implant health? A systematic review of the literature. J Biomed Mater Res B ApplBiomater. 2014;102(3):643650.

22. Kao RT, Curtis DA, Kim DM, et al. American Academy of Periodontology best evidence consensus statement on modifying periodontal phenotype in preparation for orthodontic and restorative treatment. J Periodontol. 2020;91(3):289-298.

23. Wu Q, QuY, Gong P, et al. Evaluation of the efficacy of keratinized mucosa augmentation techniques around dental implants: a systematic review.J Prosthet Dent. 2015;113(5):383-390.

24. Thoma DS, Buranawat B, Hammerle CH, et al. Efficacy of soft tissue augmentation around dental implants and in partially edentulous areas: a systematic review. J Clin Periodontol. 2014;41Suppl 15:S77-S91.

25. Esposito M, Maghaireh H, Grusovin MG, et al. Soft tissue management for dental implants: what are the most effective techniques? A Cochrane systematic review. European journal of oral implantology. 2012;5(3):221-238.

26. Bassetti RG, Stahli A, Bassetti MA, et al. Soft tissue augmentation procedures at second-stage surgery: a systematic review. Clin Oral Investig. 2016;20(7):1369-1387.

27. Ioannou AL, Kotsakis GA, McHale MG,et al. Soft Tissue Surgical Procedures for Optimizing Anterior Implant Esthetics. Int J Dent. 2015;2015:740764. 